\title{
IMPLEMENTÁCIA CESTNÉHO BALÍČKA EÚ 2020 A ODHAD JEHO DOPADOV VO VYBRANOM ČLENSKOM ŠTÁTE: SLOVENSKO
}

\author{
IMPLEMENTATION OF THE 2020 ROAD PACKAGE OF THE EU \\ AND THE ESTIMATION OF ITS IMPACT IN A SELECTED \\ MEMBER STATE: SLOVAKIA
}

Renáta Cződörová1 , Jozef Gnap ${ }^{1, *}$

\begin{abstract}
Abstrakt
Európska únia prijala v oblasti cestnej dopravy „cestný balíček“ viacerých opatrení, ktorých ciel’om je pomôct' odvetviu zachovat' si konkurencieschopnost' v rámci sociálne spravodlivej transformácie smerom k čistej energii a digitalizácii. Ciel'om predloženého balíčka do d'alšieho legislatívneho procesu na úrovni EÚ je podl'a Európskej komisie riešit' otázky vel'kej pret'aženosti ciest a znečistenia, ale tiež reagovat' na rastúci počet subjektov v cestnej nákladnej doprave a ich pracovné a sociálne podmienky. Ciel'om tohto príspevku je skúmanie vplyvu týchto nových legislatívnych zmien na podnikatel'ské prostredie v cestnej doprave vo vybranom členskom štáte EÚ v Slovenskej republike. Boli odhadnuté vybrané náklady na implementáciu balíčka na prevádzkovatel’ov cestnej dopravy.
\end{abstract}

Klíčová slova cestná doprava, nariadenie, dopravca, licencia Spoločenstva, Cestný balíček EÚ 2020

Summary The European Union has adopted a "road package" of several measures in the field of road transport, with the aim of helping the sector to remain competitive in the context of a socially just transformation towards clean energy and digitalisation. According to the European Commission, the package presented for the next legislative process at EU level aims to address the issues of extreme overload of road traffic and pollution, but also to respond to the growing number of road freight transport operators and their working and social conditions. The aim of this paper is to examine the impact of these new legislative changes on the business environment in road transport in the Slovak Republic, the selected EU Member State. Selected costs for the implementation of the package for road transport operators were estimated.

Keywords road transport, regulation, carrier, Community license, EÚ 2020 Road Package

\footnotetext{
${ }^{1}$ Žilinská univerzita v Žiline, Fakulta prevádzky a ekonomiky dopravy a spojov, Katedra cestnej a mestskej dopravy, Univerzitná 8215/1, 01026 Žilina, Slovensko

* Korešpondenčný autor, tel.: +421 415133 500, e-mail: jozef.gnap@fpedas.uniza.sk
} 


\section{1 ÚVOD}

Od 01. 05. 2004 je Slovenská republika členom Európskej únie. Európska únia v rámci stanovených cielov vydáva právne akty rôznej právnej sily. Týmito aktami sú najmä nariadenia, smernice, rozhodnutia, odporúčania a stanoviská. Z pohl'adu cestnej dopravy majú najväčší význam hlavne nariadenia a smernice. Nariadenia sú akty právne záväzné, platia v celom svojom rozsahu na území všetkých členských štátov a vydáva ich Európsky parlament a Rada. Smernice sú potom právne akty, ktoré stanovujú ciele pre členské štáty, a tie sú následne povinné stanovené ciele implementovat’ do vnútroštátnej právnej úpravy. Ciel'om týchto legislatívnych úprav je vytvorit' liberalizovaný trh cestnej dopravy otvorením prístupu na tento trh za určitých podmienok. To sa má dosiahnut' odstránením všetkých obmedzení pre prevádzkovatel'ov dopravy z dôvodu ich štátnej príslušnosti alebo skutočnosti, že majú sídlo v inom členskom štáte ako v štáte, $\mathrm{v}$ ktorom poskytujú služby, a zároveň vytvorením rovnakých podmienok. Európska únia po prvom cestnom balíku v roku 2009, ktorý mal odstránit' pomerne vel'ké disproporcie v prístupe na trh cestnej dopravy najmä medzi novými členskými štátmi EÚ, ktorí vstúpili do EÚ v roku 2004. Napríklad v Slovenskej republike sa dopravná licencia na medzinárodnú cestnú nákladnú dopravu vydávala na obdobie len 5 rokov a v Pol'sku na 50 rokov. V roku 2020 bol prijatý druhý "cestný balíček“ viacerých opatrení, ktorých ciel'om je pomôct' odvetviu zachovat' si konkurencieschopnost' v rámci sociálne spravodlivej transformácie smerom k čistej energii a digitalizácii. Hlavnými výskumnými otázkami bolo odhadnút' vybrané náklady na implementáciu balíčka na prevádzkovatel'ov cestnej dopravy a tiež zistit' kol'kých dopravcov sa dotknú zmeny v prístupe na trh s vozidlami do celkovej hmotnosti 3,5 tony.

\section{MATERIÁL A METÓDY}

\subsection{Prvý balík cestnej dopravy - 2009}

EÚ formou mnohých uznesení a správ týkajúcich sa odvetvia cestnej dopravy požadovala a podporovala postupné otvorenie trhu cestnej nákladnej dopravy a cestnej osobnej dopravy. Zároveň opakovane pripomínala, že je potrebné zaručit' liberalizáciu a zároveň harmonizáciu vrátane sociálnych aspektov a bezpečnosti dopravy. Postupne vytvorila podmienky umožňujúce vytvorenie liberalizovaného vnútorného trhu v odvetví cestnej dopravy. Vytvorenie spravodlivých podmienok hospodárskej sút’aže si však vyžadovalo d'alšiu harmonizáciu sociálnych, technických a daňových podmienok. Výsledkom bol vd’aka kompromisnej dohode medzi Parlamentom a Radou prvý balík cestnej dopravy, ktorý bol prijatý v októbri 2009. Balík tvorili tri nariadenia (EÚ) všetky sa v plnom rozsahu uplatňujú od 04. 12. 2011.

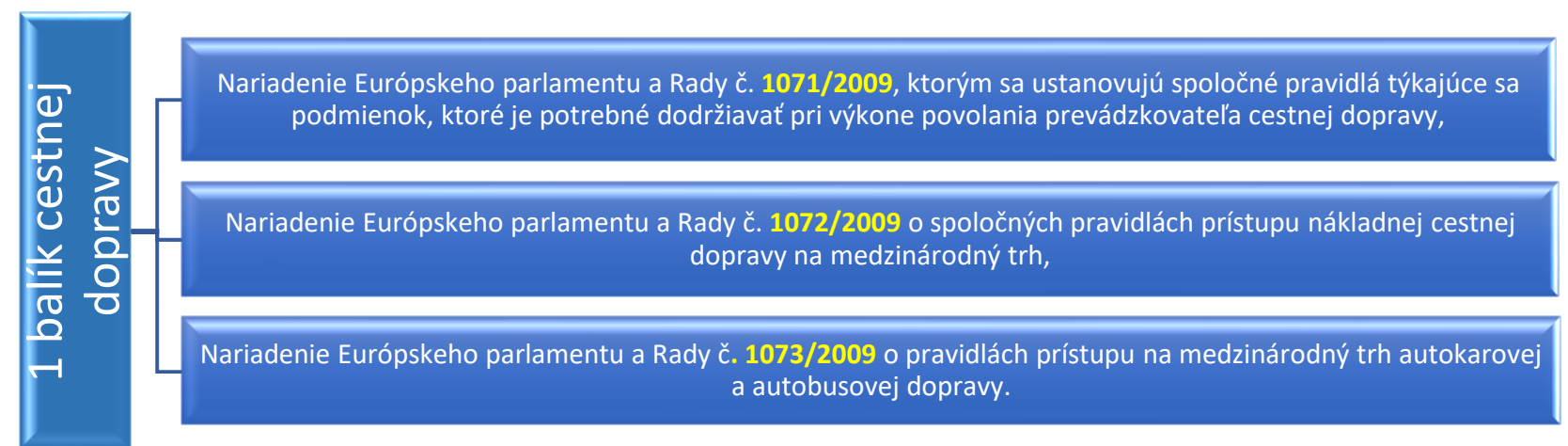

Obr. 1 Prvý balík cestnej dopravy; zdroj: autor 


\subsection{Druhý balík cestnej dopravy - 2020}

Ciel'om druhého cestného balíka opatrení v oblasti cestnej dopravy je okrem iného zlepšit' pracovné podmienky vodičov. Zavedú sa osobitné pravidlá vysielania vodičov v medzinárodnej doprave a aktualizujú sa ustanovenia o prístupe na trh nákladnej dopravy (Gnap, 2020). Zároveň sa nimi zlepší účinnost' dodržiavania predpisov. Novými pravidlami sa má docielit’ rovnováha medzi lepšími pracovnými a sociálnymi podmienkami vodičov a slobodou prevádzkovatel'ov poskytovat' cezhraničné služby, pričom sa nimi zároveň prispeje $\mathrm{k}$ bezpečnosti cestnej premávky. Okrem toho sa nimi spresnia predtým nejednoznačné ustanovenia, čo vnesie do tohto odvetvia viac jasnosti, a ukončí sa nejednotné uplatňovanie medzi členskými štátmi. Nový balík cestnej dopravy pozostáva z nariadení a smerníc zobrazených na obrázku 2.

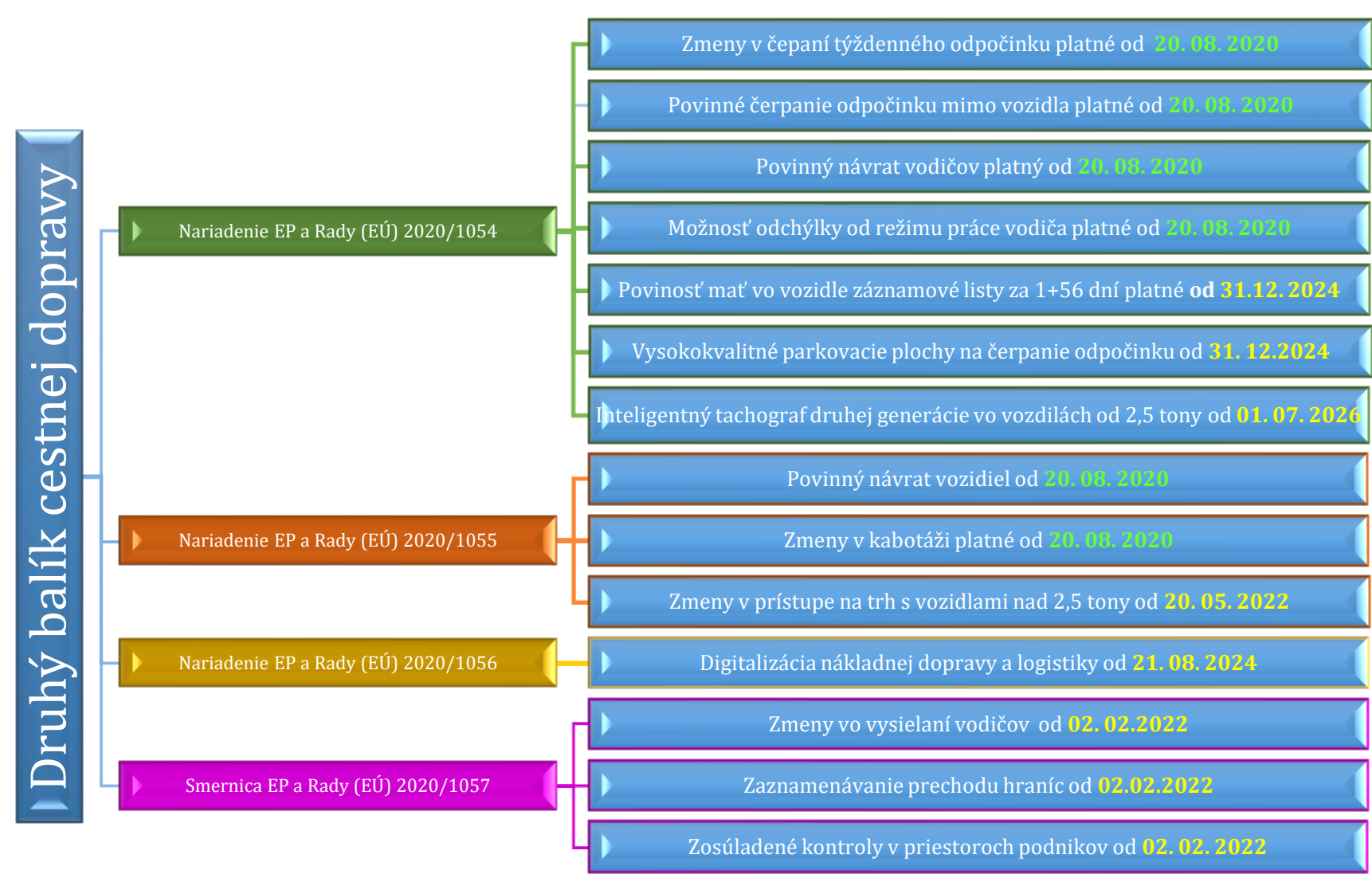

Obr. 2 Druhý balík cestnej dopravy; zdroj: autori

\section{NOVELA ZÁKONA O CESTNEJ DOPRAVE}

Aktuálne sa pripravuje novela zákona č. 56/2012 Z. z. o cestnej doprave z dôvodu vykonania nariadenia Európskeho parlamentu a Rady (EÚ) 2020/1055 z 15. 07. 2020, ktorým sa menia nariadenia (ES) č. 1071/2009, (ES) č. 1072/2009 a (EÚ) č. 1024/2012 s ciel'om prispôsobit' ich vývoju v odvetví cestnej dopravy. Nariadenie Európskeho parlamentu a Rady (EÚ) 2020/1055 sa bude uplatňovat' od 21. 02. 2022 a k tomuto dátumu je potrebné prijat’ všetky zmeny v zákone č. 56/2012 Z. z. o cestnej doprave. Novým nariadením sa rozširuje rozsah vozidiel a jazdných súprav, ktoré budú v rámci Európskej únie pri preprave tovaru podliehat' povinnosti mat' licenciu Spoločenstva. Požiadavky na prístup $\mathrm{k}$ povolaniu prevádzkovatel'a cestnej dopravy budú od 21. 05. 2022 povinné aj pre prevádzkovatel'ov, ktorí používajú motorové vozidlá alebo jazdné súpravy na prepravu tovaru v medzinárodnej doprave, ktorých najväčšia prípustná celková hmotnost' presahuje 2,5 tony, ale nepresahuje 3,5 tony. Z povinnosti mat' licenciu Spoločenstva budú nad’alej vyňaté všetky prepravy (medzinárodné aj vnútroštátne) vykonávané 
vozidlami, ktorých celková hmotnost' vrátane prípojných vozidiel nepresahuje 2,5 tony a vnútroštátne prepravy vykonávané vozidlami, ktorých celková hmotnost' vrátane prípojných vozidiel presahuje 2,5 tony, ale nepresahuje 3,5 tony. Novela zákona by mala upravit' najmä:

- podmienky finančnej spol’ahlivosti, podmienky odbornej spôsobilosti vedúceho dopravy a prevádzkovatel’a cestnej dopravy, ktorý prevádzkuje motorové vozidlá alebo jazdné súpravy na prepravu tovaru v medzinárodnej doprave, ktorých najväčšia prípustná celková hmotnost' presahuje 2,5 tony, ale nepresahuje 3,5 tony,

- kontroly prevádzkovatel'ov cestnej dopravy, ktoré by mali byt' cielene zamerané na podniky so zvýšeným rizikom,

- spôsob výmeny informácií medzi členskými štátmi. Informácie sa budú vymieňat' okrem elektronického registra prevádzkovatel'ov cestnej dopravy aj prostredníctvom informačného systému o vnútornom trhu tzv. IMI systém, ktorý je už v súčasnosti využívaný na spoluprácu medzi členskými štátmi Európskej únie a Európskou komisiou v iných oblastiach,

- oblast' prepravy nebezpečných vecí,

- sankcie, kompetencie a iné ustanovenia.

Návrh zákona sa týka najmä prevádzkovatel'ov cestnej dopravy, ktorí používajú motorové vozidlá alebo jazdné súpravy na prepravu tovaru v medzinárodnej doprave, ktorých najväčšia prípustná celková hmotnost' presahuje 2,5 tony, ale nepresahuje 3,5 tony. Títo patria v súčasnosti pod pôsobnost' zákona č. 455/1991 Zb. o živnostenskom podnikaní (živnostenský zákon) v znení neskorších predpisov. Ministerstvo vnútra SR eviduje iba celkový počet vydaných živností s predmetom činnosti 4902 - Nákladná cestná doprava vykonávaná vozidlami s celkovou hmotnost'ou do 3,5 t vrátane prípojného vozidla, ktorých je v súčasnosti viac ako 160000 a je možné predpokladat', že aj väčšina týchto subjektov zostane nad'alej pod pôsobnost’ou zákona č. 455/1991 Zb. o živnostenskom podnikaní (živnostenský zákon).

Tab. 1 Podnikatel'ské subjekty s predmetom podnikania -

Nákladná cestná doprava vykonávaná vozidlami s celkovou hmotnost’ou do 3,5 t; zdroj: autori na základe údajov Živnostenského registra SR

\begin{tabular}{cc}
\hline Kraj & $\begin{array}{c}\text { Počet podnikatel'ských subjektov } \\
\text { evidovaných v Živnostenskom registri SR } \\
\text { v roku 2020 }\end{array}$ \\
\hline Bratislavský kraj & 37508 \\
Trnavský kraj & 16311 \\
Trenčiansky kraj & 15309 \\
Nitriansky kraj & 21899 \\
Žilinský kraj & 21789 \\
Banskobystrický kraj & 16302 \\
Prešovský kraj & 18407 \\
Košický kraj & 18329 \\
\hline Spolu & $\mathbf{1 6 5 8 5 4}$
\end{tabular}

V Slovenskej republike bolo podl'a štatistiky Ministerstva vnútra SR k 31. 12. 2020 v kategórií nákladných vozidiel N1 s celkovou hmotnost'ou do 3,5 tony evidovaných 243659 vozidiel pričom v rozsahu od 2,5 tony do 3,5 tony 148689. 


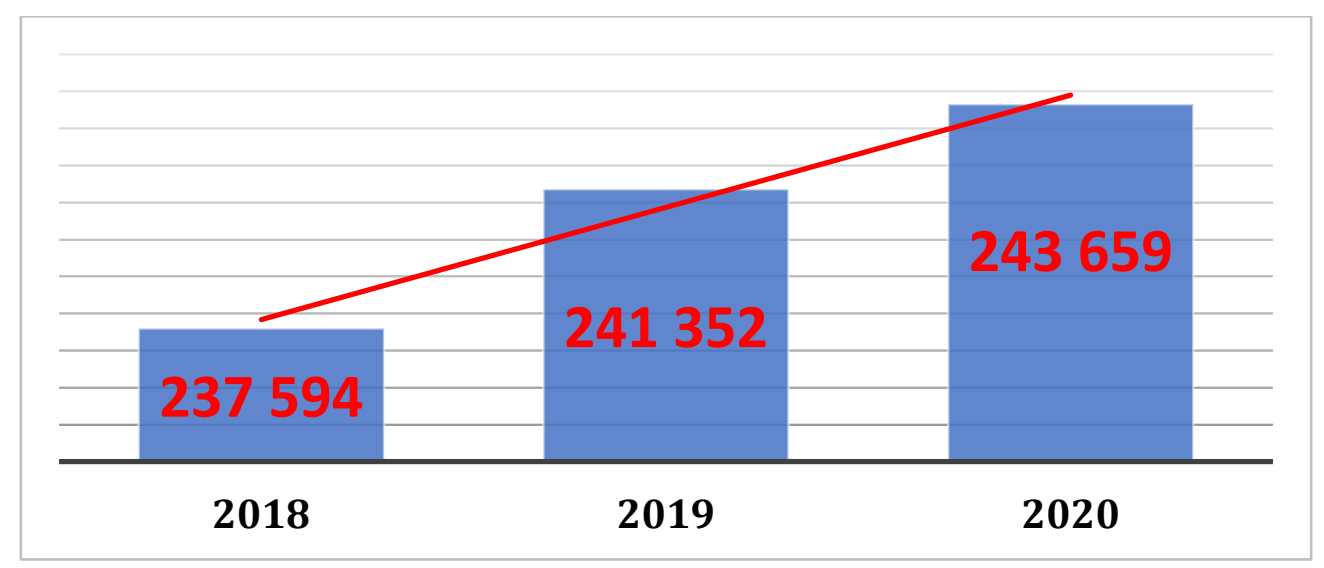

Obr. 3 Evidované vozidlá kategórie N1 od roku 2018 do roku 2020; zdroj: autori na základe údajov MV SR

Návrh zákona o cestnej doprave sa bude týkat' aj prevádzkovatel'ov cestnej dopravy, ktorí sú držitel’mi licencie Spoločenstva pre nákladnú dopravu a držitel'mi licencie Spoločenstva na medzinárodnú osobnú prepravu autobusmi a autokarmi. K 31. 12. 2020 bolo v Slovenskej republike evidovaných 9043 prevádzkovatel'ov cestnej nákladnej dopravy a z toho 7152 dopravcov, ktorí boli aj držitel'mi licencie Spoločenstva pre nákladnú dopravu. Títo dopravcovia mali vydané overené kópie licencií Spoločenstva pre vozidlá v počte 53662 .

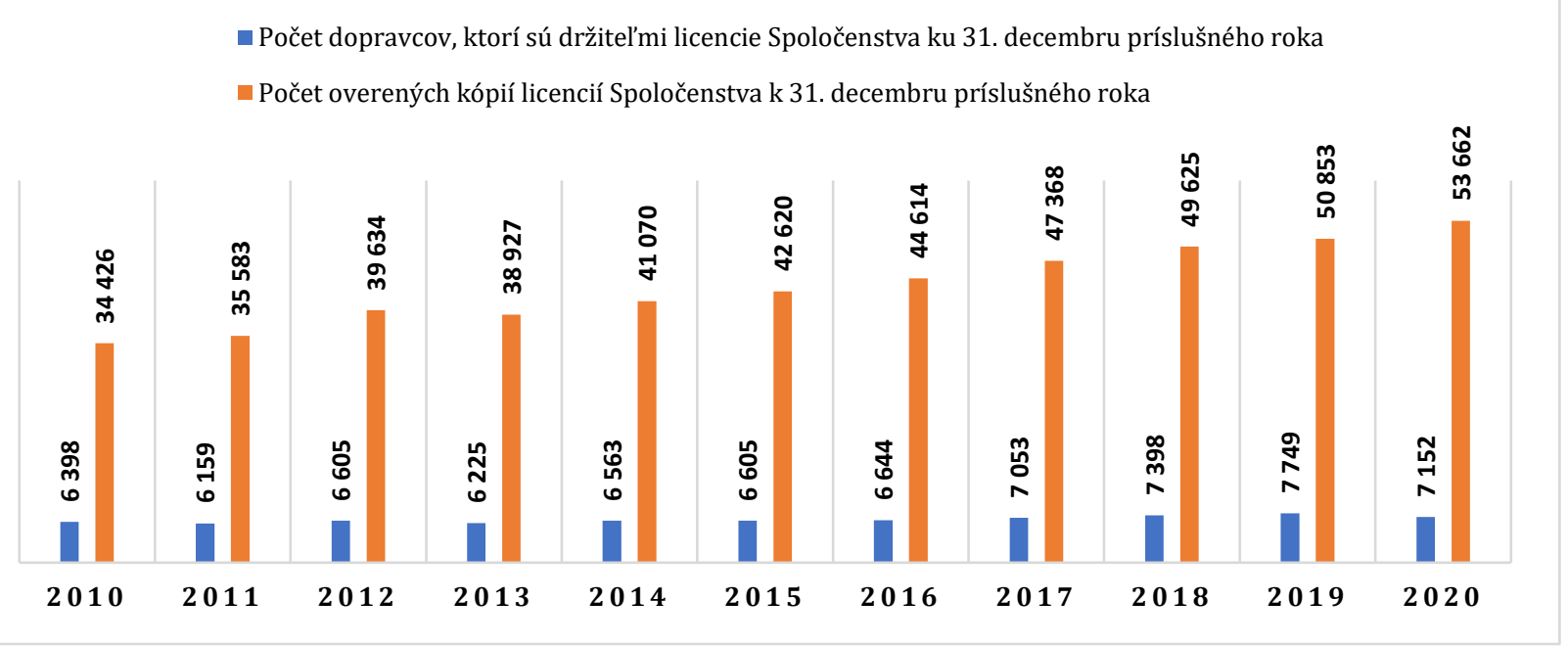

Obr. 4 Prevádzkovatelia medzinárodnej cestnej nákladnej dopravy; zdroj: autori na základe údajov z jiscd.sk

K 31. 12. 2020 bolo v Slovenskej republike evidovaných 1004 prevádzkovatel’ov cestnej osobnej dopravy a z toho 826 dopravcov bolo aj držitel'mi licencie Spoločenstva na medzinárodnú osobnú prepravu autobusmi a autokarmi. Títo dopravcovia mali vydaných 4058 overených kópii licencií Spoločenstva pre ich vozidlá. 


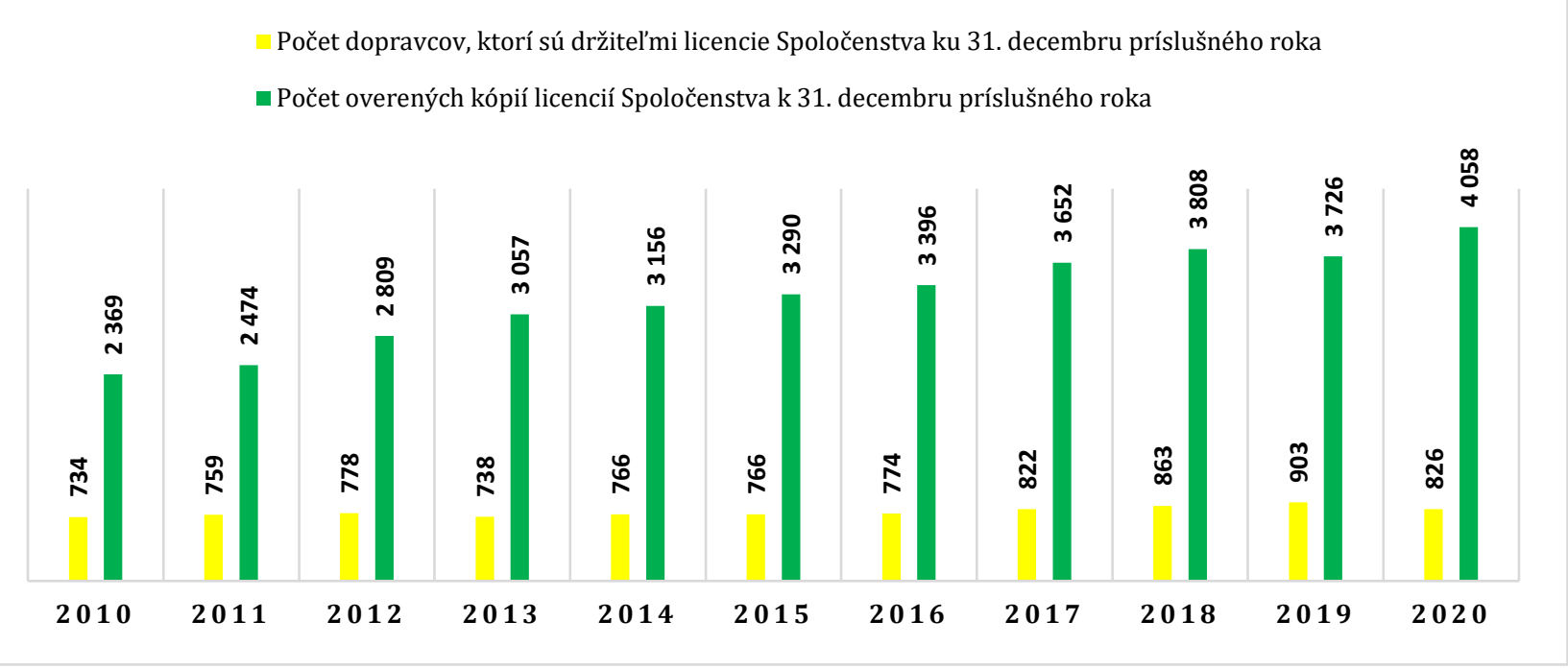

Obr. 5 Prevádzkovatelia medzinárodnej cestnej osobnej dopravy; zdroj: autori na základe údajov z jiscd.sk

\section{NOVELA ZÁKONA O ORGANIZÁCII PRACOVNÉHO ČASU V DOPRAVE}

Zmeny ktoré prináša nový balík cestnej dopravy sa dotknú aj zákona č. 462/2007 Z. z. o organizácii pracovného času v doprave a o zmene a doplnení zákona č. 125/2006 Z. z. o inšpekcii práce a o zmene a doplnení zákona č. 82/2005 Z. z. o nelegálnej práci a nelegálnom zamestnávaní a o zmene a doplnení niektorých zákonov v znení zákona č. 309/2007 Z. z. v znení neskorších predpisov a ktorým sa menia a dopíňajú niektoré zákony. Ciel’om novely zákona je transpozícia smernice Európskeho parlamentu a Rady (EÚ) 2020/1057 z 15. 07. 2020, ktorou sa stanovujú špecifické pravidlá vo vzt’ahu k smernici 96/71/ES a smernici 2014/67/EÚ pre vysielanie vodičov v odvetví cestnej dopravy a ktorou sa mení smernica 2006/22/ES, pokial' ide o požiadavky týkajúce sa dodržiavania predpisov, a nariadenia (EÚ) č. 1024/2012 (d’alej len „smernica Európskeho parlamentu a Rady (EÚ) 2020/1057“). Zároveň sa predmetným návrhom zabezpečí vykonanie Nariadenia Európskeho parlamentu a Rady (EÚ) 2020/1054 z 15. 07. 2020, ktorým sa mení nariadenie (ES) č. 561/2006, pokial' ide o minimálne požiadavky na maximálne denné a týždenné časy jazdy, minimálne prestávky a doby denného a týždenného odpočinku, a nariadenie (EÚ) č. 165/2014, pokial' ide o určovanie polohy prostredníctvom tachografov.

V súčasnosti platný zákon č. 462/2007 Z. z. ustanovuje minimálne požiadavky na organizáciu pracovného času v doprave. Upravuje pravidlá týkajúce sa vykonávania cestných kontrol a kontrol dopravných podnikov ako aj pôsobnost' orgánov štátnej správy $\mathrm{v}$ uvedených oblastiach. Subsidiárne sa na pracovnoprávne vzt’ahy zamestnancov v doprave vzt'ahuje Zákonník práce.

Nový zákon s účinnost'ou od 02. 02. 2022 by mal zjednotit' pravidlá vysielania vodičov v odvetví cestnej dopravy v rámci Európskej únie. Určí, že medzinárodná doprava v tranzite cez územie členského štátu nepredstavuje vysielanie a zároveň určí aj to, ktoré dopravné činnosti majú výnimku z pravidiel týkajúcich sa vysielania, a to najmä v súvislosti s bilaterálnymi prepravami medzi členskými štátmi Európskej únie. Kabotážna preprava bude považovaná za vysielanie. Informácie a doklady k vysielaniu sa budú vymieňat' prostredníctvom informačného systému o vnútornom trhu, ktorý je už v súčasnosti využívaný na spoluprácu medzi členskými štátmi Európskej únie a Európskou komisiou. 


\section{NÁKLADY REGULÁCIE}

\subsection{Odhad nákladov regulácie pre nových prevádzkovatel’ov cestnej dopravy}

Vykonávat' povolanie prevádzkovatel'a cestnej dopravy môže spoločnost' len na základe povolenia. Je nevyhnutné splnit’ špecifické podmienky pre získanie povolenia na prevádzkovanie cestnej nákladnej alebo osobnej dopravy a následne licencie Spoločenstva na vykonávanie medzinárodnej dopravy (Gnap et al., 2019). Povolenie aj licenciu Spoločenstva udel'uje miestne príslušný okresný úrad v sídle kraja na požadovaný počet motorových vozidiel. (Cződörová et al., 2020) Spoločnost' ktorá sa rozhodne podnikat' v cestnej doprave musí teda na začiatku svojho podnikania rátat' s prvotnými nákladmi vo forme správnych poplatkoch uvedených v tabul'ke 2 na získanie všetkých potrebných dokladov. Na získanie licencie Spoločenstva pre nových prevádzkovatel'ov cestnej dopravy budú vo výške 163 EUR, v prípade, že dopravca bude podnikat' s jedným nákladným vozidlom.

Tab. 2 Správne poplatky pre nových dopravcov; zdroj: autor

\begin{tabular}{lr}
\hline Vydanie povolenia na výkon povolania prevádzkovatel'a cestnej dopravy & 30 EUR \\
Vydanie licencie Spoločenstva & 20 EUR \\
Vydanie overenej kópie licencie Spoločenstva na každé vozidlo & 3 EUR \\
Vykonanie skúšky odbornej spôsobilosti v oblasti cestnej dopravy & 100 EUR \\
Vydanie osvedčenia o odbornej spôsobilosti v cestnej doprave & 10 EUR \\
\hline Spolu & 163 EUR \\
\hline
\end{tabular}

Nie je možné stanovit' aký počet prevádzkovatel'ov cestnej dopravy bude mat' takúto povinnost'. Ministerstvo dopravy a výstavby SR odhaduje, že pribudne 5000 nových prevádzkovatel'ov cestnej medzinárodnej dopravy, ktorí momentálne vykonávajú prepravy s vozidlami do 3,5 tony a budú mat' teda povinnost' mat' povolenie. Náklady na podnikatel'ské prostredie sa teda odhadujú na 815000 eur (5 000 x 163 eur). V prípade, že by bola zavedená možnost' elektronických podaní, náklady pre nových prevádzkovatel’ov cestnej dopravy by náklady mohli byt' nižšie.

Ďalšie nepriame finančné náklady môžu vzniknút' prechodom subjektov z rozsahu zákona č. 455/1991 Zb. o živnostenskom podnikaní (živnostenský zákon) vznení neskorších predpisov pod zákon č. 56/2012 Z. z. o cestnej doprave v znení neskorších predpisov. Tieto zmeny môžu súvisiet' s plnením podmienok finančnej spol'ahlivosti, odbornej spol'ahlivosti, povinnosti mat' technickú základňu, prepravný poriadkom, označené vozidlá a povinnosti, ktoré súvisia s podnikaním podl'a Nariadení Európskeho parlamentu a Rady 1071/2009 a 1072/2009. Náklady môžu vzniknút' aj s organizáciou práce vodičov nakol'ko na tento segment sa začnú uplatňovat' podmienky kabotáže a od 01. 07. 2026 aj podmienky zaznamenávania pracovného času záznamovým zariadením (Poliak a Gnap, 2020). Vozidlá ktoré sa budú používat' v medzinárodnej doprave na prepravu tovaru, ktorých najväčšia prípustná celková hmotnost' vrátane prípojných vozidiel bude presahovat' 2,5 tony budú musiet' byt' vybavené záznamovým zariadením - inteligentným tachografom druhej generácie. Náklady na montáž záznamového zariadenia vrátane montáže potrebných súčastí, a overenia budú závisiet' od ponuky na trhu avšak podl'a dostupných zdrojov na internete sa momentálne tieto náklady pohybujú vo výške 1200 EUR na jedno vozidlo. Tak isto netreba zabudnú na náklady na vodiča, ktorý bude potrebovat' kartu vodiča do záznamového zariadenia, ktorej cena je momentálne 54 EUR.

Ak by sa montáž záznamových zariadení týkala už spomínaných odhadovaných 5000 vozidiel tak náklady na montáž na celé podnikatel'ské prostredie by tvorili sumu 6000000 eur (5 000 vozidiel x 1200 EUR za montáž, overenie a kartu vodiča). Uvedená povinnost' inštalácie záznamového zariadenia do vozidiel s hmotnost'ou presahujúcou 2,5 tony bude mat' pozitívny dopady najmä pre podnikatel'ské subjekty, ktoré zabezpečujú inštaláciu, overovanie a výmenu tachografov. Návrh zákona sa bude týkat' aj 2 registrovaných dielní a 17 autorizovaných dielní vrátane pracovísk pre vykonávanie inštalácie a overovanie záznamových zariadení. 
Momentálne Európska únia nestanovila povinnost' podrobit' sa kurzu základnej kvalifikácie alebo pravidelného výcviku vodičov, ktorí budú viest' vozidla s hmotnost'ou presahujúcou 2,5 tony. Do budúcna to však môže predstavovat' riziko d'alších nákladov pre prevádzkovatel'ov cestnej dopravy s týmito vozidlami a ich vodičov.

\subsection{Odhadované náklady pre existujúcich prevádzkovatel’ov cestnej dopravy}

Podl’a článku 16 ods. 5 a 6 nariadenia (ES) č. 1071/2009 sa vyžaduje, aby vnútroštátne elektronické registre prevádzkovatel'ov cestnej dopravy boli navzájom prepojené. Podmienky týkajúce sa prepojenia vnútroštátnych elektronických registrov podnikov cestnej dopravy sú ustanovené vo vykonávacom nariadení Komisie (EÚ) 2016/480, ktorým sa stanovujú spoločné pravidlá týkajúce sa vzájomného prepojenia vnútroštátnych elektronických registrov podnikov cestnej dopravy. V súvislosti s cezhraničným presadzovaním ustanovení nariadení (ES) č. 1071/2009 a (ES) č. 1072/2009 sa do vnútroštátneho elektronického registra prevádzkovatel’ov cestnej dopravy dopíňajú okrem iného aj informácie o evidenčných číslach vozidiel, ktoré majú prevádzkovatelia k dispozícii. Súčasne vydané overené kópie licencie Spoločenstva sú vydávané bez evidenčného čísla. Na zabezpečenie tejto povinnosti bude potrebné opätovne vydat' všetky overené kópie licencie Spoločenstva do 02. 08. 2023. Správny poplatok za vydanie overenej kópie licencie Spoločenstva na každé vozidlo je 3 eur.

Do roku 2023 bude teda potrebné vydat' nové overené kópie licencie Spoločenstva s už uvedeným evidenčným číslom vozidla pre minimálne 57720 vozidiel $(53662$ evidovaných overených kópií licencie Spoločenstva pre nákladné vozidlá a 4058 evidovaných overených kópií licencie Spoločenstva pre autobusy). Pre celý podnikatel'ský sektor to bude predstavovat' sumu 173160 Eur (57 720 vozidiel x 3 EUR - poplatok za vydanie overenej kópie licencie Spoločenstva).

Ďalšie náklady pre existujúcich prevádzkovatel'ov cestnej dopravy prichádzajú s nariadením Európskeho parlamentu a Rady (EÚ) 2020/1054 ktorým sa zavádzajú inteligentné tachografy druhej generácie (Gnap 2019). Inteligentný tachograf druhej generácie bude automaticky zaznamenávat' prekročenie hraníc, bude zaznamenávat' polohu pri nakládke a vykládke a zlepší monitorovanie doby jazdy a odpočinku. Inteligentný tachograf druhej generácie bude z hl'adiska funkčnosti viac odolný voči manipulácií a bude mat' prípravu na autentifikáciu satelitného signálu Galileo, akonáhle bude systém Galileo funkčný (Baldinia et al., 2018). Inteligentný tachograf druhej generácie by už mal byt' prispôsobený na implementovanie budúcich nových špecifikácií prostredníctvom aktualizácií softvéru bez nutnosti fyzickej výmeny. Časový harmonogram pre zavedenie inteligentných tachografov druhej generácie závisí od vykonávajúceho nariadenia, ktoré musí prijat’ Európska komisia do 21. 08. 2021.

\begin{tabular}{|c|c|}
\hline & $\begin{array}{l}\text { •Inteligentné tachografy druhej generácie budú inštalované v nových vozidlách, ktorých } \\
\text { prvá evidencia bude od 21. 08. 2023. }\end{array}$ \\
\hline & $\begin{array}{l}\text { - Povinná výmena analógových tachografov a digitálnych tachografov vo vozidlách, ktoré } \\
\text { budú vykonávat' medzinárodnú dopravu za inteligentné tachografy druhej generácie sa } \\
\text { musí uskutočnit' do } \mathbf{3 1 . 1 2 . 2 0 2 4} \text {. }\end{array}$ \\
\hline & $\begin{array}{l}\text { - Povinná výmena inteligentných tachografov prvej generácie vo vozidlách, ktoré budú } \\
\text { vykonávat' medzinárodnú dopravu za inteligentné tachografy druhej generácie bude do } \\
\text { 21. 08. } 2025\end{array}$ \\
\hline & $\begin{array}{l}\text { u, u ktorých maximálna celková prípustná hmotnost' } \\
\text { o návesu je vyššia ako } 2,5 \text { ton. }\end{array}$ \\
\hline
\end{tabular}

Obr. 6 Časový harmonogram zavedenia inteligentných tachografov druhej generácie; zdroj: autori 
Výmena tachografu vo vozidlách bude samozrejme závisiet’ od prevádzkovatel’ov cestnej dopravy či budú vykonávat' medzinárodnú cestnú dopravu alebo nie. Významným faktorom pre výmenu môže byt' aj to, že vozidlá vybavené inteligentným tachografom druhej generácie môžu využívat' vo väčšej miere výnimky z vysielania. Z tohto dôvodu je možné očakávat', že dopravcovia budú mat' záujem o výmenu v skoršom termíne, potom čo bude inteligentný tachograf druhej generácie dostupný na trhu. Náklady na výmenu vrátane potrebných súčastí, montáže, overenia digitálneho tachografu, inteligentného tachografu prvej generácie za inteligentných tachograf druhej generácie budú závisiet’ od ponuky na trhu v danom čase, avšak tieto náklady je možné odhadovat' vo výške 1200 eur/vozidlo. Nie je možné presne stanovit', aký bude počet vozidiel v ktorých sa tieto nové inteligentné tachografy budú vymieňat'. Ak by sa však výmena týkala v roku 2024 všetkých vozidiel ktoré majú aktuálne vydanú licenciu Spoločenstva a je predpoklad, že medzinárodnú dopravu vykonávajú (57 720 vozidiel) tak náklady na výmenu na celé podnikatel'ské prostredie by tvorili sumu 69264000 eur (28 860 vozidiel x 1200 eur).

Výmena tachografov bude mat' negatívne dopady pre prevádzkovatel'ov cestnej dopravy avšak naopak pozitívne dopady to môže mat' pre podnikatel'ské subjekty zabezpečujúce predaj, výmenu a overovanie tachografov. Vzhl'adom vysoký počet vozidiel podliehajúcich výmene môžu dôjst' $\mathrm{k}$ problémom so zvládnutím kapacitných možností pracovísk zabezpečujúcich výmenu a overovanie.

Medzi d'alšie náklady, ktoré musia prevádzkovatelia cestnej dopravy s príchodom nového balíka cestnej dopravy znášat', sú náklady na ubytovanie pre vodiča. Vodiči nákladných vozidiel nesmú čerpat’ doby pravidelného týždenného odpočinku a každú dobu týždenného odpočinku v trvaní viac ako 45 hodín vo vozidle (Gnap, 2020). V tejto súvislosti vzniknú prevádzkovatel’om cestnej dopravy zvýšené náklady na ubytovanie vodiča. (Gnap et al., 2020). Presné náklady nie je možné vyčíslit', nakol'ko tieto náklady závisia od organizácii práce vodiča, prípadne aj od druhu a kvality ubytovania a dostupnost' z parkovísk určených pre nákladnú cestnú dopravu (Poliak et al., 2020). Odhadované náklady na ubytovanie, cestu na ubytovanie, strážené parkovisko vozidla sa môžu v niektorých prípadoch v závislosti od štátu Európskej únie pohybovat' aj na úrovni cca 250 eur/vozidlo/vodič/mesiac.

Nie je možné presne stanovit' $\mathrm{v}$ akom počte a $\mathrm{v}$ akých nákladoch takáto povinnost' bude mat' dopad na podnikatel'ské prostredie avšak, ak by sa táto povinnost' týkala napríklad $10 \%$ vozidiel ktoré majú vydanú licenciu Spoločenstva (5 772), tak náklady na podnikatel'ské prostredie by tvorili sumu 1443000 mesačne, a na celé podnikatel'ské prostredie by ročné náklady boli vo výške 17316000 Eur (57 720 licencií Spoločenstva, 10 \% tvorí 5772 . 250 eur = 1443000 eur x 12 mesiacov).

Tab. 3 Súhrnná tabul'ka odhadovaných nákladov regulácie pre podnikatel'ské prostredie; zdroj: autori

\begin{tabular}{|c|c|c|}
\hline Náklady regulácie & Náklady & $\begin{array}{c}\text { Náklady na celé podnikatel'ské } \\
\text { prostredie }\end{array}$ \\
\hline $\begin{array}{c}\text { Správny poplatok - noví prevádzkovatelia cestnej } \\
\text { dopravy s vozidlami nad } 2,5 \mathrm{t}\end{array}$ & 163 eur/subjekt & 815000 eur $/ 5000$ subjektov \\
\hline $\begin{array}{c}\text { Montáž záznamových zariadení - noví } \\
\text { prevádzkovatelia cestnej dopravy s vozidlami } \\
\text { nad } 2,5 \mathrm{t}\end{array}$ & 1200 eur/vozidlo & 6000000 eur $/ 5000$ subjektov \\
\hline $\begin{array}{c}\text { Správny poplatok - existujúci prevádzkovatelia } \\
\text { cestnej dopravy na vydanie overenej kópie } \\
\text { licencie Spoločenstva }\end{array}$ & 3 eur/vozidlo & 173160 eur/57 720 vozidiel \\
\hline $\begin{array}{c}\text { Vybavenie vozidla inteligentným tachografom } \\
\text { druhej generácie }\end{array}$ & 1200 eur/vozidlo & 69264000 eur/57 720 vozidiel \\
\hline Čerpanie pravidelného odpočinku mimo vozidla & 250 eur/vozidlo & 17316000 eur /5 772 vozidiel/rok \\
\hline Celkové náklady regulácie & 2816 eur & 93568160 eur \\
\hline
\end{tabular}




\subsection{Administratívne náklady}

Pozitívom právnej úpravy pri zjednotení pravidiel v oblasti vysielania vodičov v odvetví cestnej dopravy pre podnikatel'ské prostredie sú najmä jednotné podmienky v rámci Európskej únie. Členské štáty nebudú zavádzat' rôzne národné úpravy, čiže prevádzkovatelia cestnej dopravy pokial' budú vykonávat' prepravy v rámci povolených výnimiek sa nich nebudú vzt’ahovat' podmienky vysielania v iných členských štátoch. Nevýhodou je, že v rámci jednotného trhu ak dopravcovia budú vykonávat' prepravy nad rozsah, ktorý im povol'ujú výnimky budú musiet' pred vyslaním nahlásit' a priebežne aktualizovat' údaje ohl'adom vysielania v informačnom systéme o vnútornom trhu tzv. IMI systéme.

Informácie a doklady k vysielaniu sa budú vymieňat' prostredníctvom informačného systému o vnútornom trhu, ktorý je už v súčasnosti využívaný na spoluprácu medzi členskými štátmi Európskej únie a Európskou komisiou. Prevádzkovatel’om systému IMI je Európska komisia a v tejto súvislosti pre Slovenskú republiku nevzniknú náklady z hladiska informatizácie. Administratívne náklady môžu vzniknút’ dopravcom, ktorí nebudú patrit' pod výnimky z vysielania a ktorí budú musiet' poskytovat' informácie z hl'adiska vysielania v systéme IMI.

\subsection{Náklady na zmeny $\mathrm{v}$ jednotnom informačnom systéme $\mathrm{v}$ cestnej doprave}

V súvislosti s cezhraničným presadzovaním ustanovení nariadení (ES) č. 1071/2009 a (ES) č. 1072/2009 sa do vnútroštátneho elektronického registra prevádzkovatel’ov cestnej dopravy budú dopíňat' informácie o evidenčných číslach vozidiel, ktoré majú prevádzkovatelia cestnej dopravy k dispozícii a taktiež sa zavedie povinnost' uvádzat' počet osôb zamestnaných u prevádzkovatel'a cestnej dopravy k 31. 12. predchádzajúceho kalendárneho roku. A pribudne aj informácia o hodnotení rizikovosti prevádzkovatel'ov cestnej dopravy. Tieto zmeny vyvolajú dopad na úpravu Jednotného informačného systému v cestnej doprave (d'alej len „JISCD“) a to aj spolu so zmenami, ktoré vyplývajú s navrhovanými zmenami zákona č. 56/2012 Z. z. Doposial' nie sú k dispozícii finálne technické špecifikácie, ktoré Európska komisia vydá prostredníctvom vykonávacích aktov. Na základe dostupných informácii a podkladov od dodávatel’a JISCD Ministerstvo dopravy a výstavby odhaduje finančný dopadov na systém JISCD vo výške pol milióna eur s DPH.

\section{DISKUSIA A ZÁVER}

Prvé zmeny v oblasti cestnej dopravy, ktoré Nariadenia Európskeho parlamentu a Rady (EÚ) 2020/1054 prinieslo, sú už od 20. 08. 2020 platné a podstatne ovplyvňujú režim práce vodičov a plánovanie preprav. Zabezpečit' pravidelný týždenný odpočinok vodiča mimo vozidla je vel'mi náročné, či už z finančnej alebo logistickej stránky. V krajinách EÚ nie je dostatok zabezpečených parkovacích zariadení, ktoré by mohli poskytnút' aj ubytovanie vodičom a možnost' opustit' vozidlo na 45 hodín bez dozoru, je z pohl'adu vodiča nemožné, nakol'ko vystavuje prepravovaný tovar riziku odcudzenia. Povinnost' čerpat' odpočinok mimo vozidla a s tým súvisiaci nedostatok parkovacích miest pre už existujúce nákladne vozidlá predstavuje jeden z prvých problémov, ktorý nový balík cestnej dopravy priniesol. Z dôvodu prijatých preventívnych opatrení proti šíreniu pandémie koronavírusu COVID-19 sa nevykonával vel'ký počet kontrol na pozemných komunikáciách a preto reálne dopady ešte nie je možné presne vyhodnotit'.

Ďalšie rozsiahle zmeny v oblasti cestnej dopravy v EÚ ale aj na Slovensku sa začnú uplatňovat’ už v roku 2022 kedy na základe zmeny legislatívy EÚ dochádza $\mathrm{k}$ zavedeniu podmienok podnikania prevádzkovatel'ov cestnej dopravy, ktorí budú vykonávat' medzinárodnú prepravu tovaru vozidlami, ktorých najväčšia prípustná celková hmotnost' presahuje 2,5 tony, ale nepresahuje 3,5 tony. Záujem o podnikanie s vozidlami do 3,5 tony dokazuje aj skutočnost', že najviac registrovaných nákladných vozidiel v SR je práve kategórie N1. Na základe vyhodnotenia prieskumov, realizovaných na cestnej sieti v SR, je možné tvrdit', že spomedzi nákladných vozidiel sú tieto vozidlá v cestnej premávke druhou 
najpočetnejšou kategóriu a využívajú sa aj pri medzinárodných prepravách. Najmä vd’aka možnosti realizácie prepráv na vel'ké vzdialenosti v relatívne krátkom čase nachádzajú vozidlá do 3,5 tony svoje opodstatnenie. Ide o reguláciu tohto odvetvia v rámci Európskej únie čo bude mat' za následok nemalé zvýšené náklady na celé podnikatel'ské prostredie $v$ cestnej doprave. Zároveň ide o harmonizáciu podmienok v rámci Európskej únie a získanie licencie Spoločenstva, z tohto dôvodu v tomto segmente by nemali platit' d'alšie národné podmienky. $V$ niektorých prípadoch to môže mat' aj pozitívny dopad na rozvoj dopravných služieb. Je preto potrebné už teraz mysliet' na to, aby nedochádzalo pri plnení d’alších povinností, ktoré prichádzajú s novým cestným balíčkom k situácii obdobnej ako pri plnení povinnosti čerpat' odpočinok mimo vozidla. Štát by mal mysliet' na to, že bude potrebné registrovat' vel'ké množstvo nových dopravcov s vozidlami s hmotnost'ou väčšou ako 2, 5 t a bude potrebné zabezpečit' dostatok zamestnancov a časového priestoru na rýchle vydanie nových povolení na výkon povolania prevádzkovatel'a cestnej dopravy aj licencií Spoločenstva, aby nedochádzalo k zamedzovaniu vykonávania tejto činnosti. Dopravcovia, ktorých sa táto povinnost' bude týkat' by naopak mali mysliet' na to, aby včas podali žiadost' o vydanie všetkých potrebných dokumentov. Tak isto je potrebné mat' na mysli, že bude nutné pre vydanie vel'kého množstva už existujúcich licencií Spoločenstva už pre existujúcich dopravcov, čo by tak isto mohlo obmedzit' vykonávanie medzinárodnej cestnej dopravy.

V príspevku sú odhadnuté náklady na prevádzkovatel'ov cestnej dopravy, ktoré je možné ešte spresnit' najmä o náklady potrebné na prípravu žiadostí o vydanie nových licencií resp. overených licencii spoločenstva, na pravidelnú kontrolu záznamových zariadení, ktoré sa môžu vykonávat' len v autorizovaných pracoviskách. Tu bude potrebné kalkulovat' aj náklady na cestu na úrady, autorizované pracoviská a náklady na pracovníkov, ktorí budú tieto činnosti u prevádzkovatel'ov cestnej dopravy vykonávat'.

Na druhej strane bude možné niektoré náklady do budúcnosti znížit' využitím autonómnych dopravných vozidiel (Moravčík 2020). Rýchly technologický vývoj prináša postupnú automatizáciu systémov jazdy, ktorá si vyžaduje menej priamych zásahov vodiča alebo ich vôbec nevyžaduje. Na zohl'adnenie týchto zmien bude možno potrebné upravit' súčasné právne predpisy vrátane pravidiel o časoch jazdy a dobách odpočinku, a to s ciel'om zaručit' bezpečnost' cestnej premávky a rovnaké podmienky, zlepšit' pracovné podmienky a zároveň umožnit' Únii byt' priekopníkom v oblasti nových inovačných technológií a postupov. Európska komisia do 31. decembra 2025 vypracuje a predloží Európskemu parlamentu a Rade správu hodnotiacu používanie systémov autonómnej jazdy v členských štátoch. Táto správa sa zameria najmä na potenciálny vplyv uvedených systémov na pravidlá o časoch jazdy a odpočinku. K tejto správe sa v prípade potreby pripojí legislatívny návrh na zmenu nariadenia EP a Rady (EÚ) 2020/1054. Preto prevádzkovatelia cestnej dopravy by mali neustále sledovat' aj legislatívny proces v tejto oblasti a pripravit' sa na možné výhody využitia autonómnych vozidiel.

\section{Literatúra}

Baldini, G., Sportiello, L., Chiaramello, M., Mahieu, V., 2018, Regulated applications for the road transportation infrastructure: The case study of the smart tachograph in the European Union, International Journal of Critical Infrastructure Protection, 3-21 <https://doi.org/10.1016/j.ijcip.2018.02.001>.

Cena inteligentného tachografu, Dostupné z: https://www.tamex.sk/Inteligentne-tachografyc56_253_2.htm [cit.: 2021, 03. 05.].

Ceny čipových kariet, Dostupné z: http://www.digitalnytachograf.sk/aktuality-15.html?id=57 [cit.: 2021, 03. 05].

Cződörová, R., Gnap J., Senko, Š.: 2020, Porovnanie požiadaviek na podnikanie a prevádzku nákladných vozidiel s celkovou hmotnost'ou do a nad 3,5 tony, Svet dopravy, č. 1/2020ISSN 1338 -962, 56-66, Dostupné z: http://www.svetdopravy.sk/porovnanie-poziadaviek-na-podnikanie-a-prevadzkunakladnych-vozidiel-s-celkovou-hmotnostou-do-a-nad-35-tony/, [05. 05. 2021]. 
Gnap, J., 2020, Cestný balíček EÚ 2020 - I, Výber z hl'adiska cestnej nákladnej doprave pre členov ZLZ SR; https://zlz.sk/wp-content/uploads/2020/11/Cestn\%C3\%BD-bali\%C4\%8Dek-2020-I-

\%C3\%A1kladn\%C3\%A9-inform\%C3\%A1cie.pdf, [05. 05. 2021].

Gnap, J., Poliak, M., Konečný, V., Jagelčák, J., Rievaj, 2019, Odborná spôsobilost' vedúceho dopravy a prevádzkovatel'a cestnej nákladnej dopravy. EDIS - vydavatel'stvo ŽU, Žilina,. ISBN 978-80-554-1580-2.

Gnap, J., Konečný, V., Slávik, R., Beňová, D., 2018, Possible Impacts of Regulating the Weekly Rest of Road Freight Drivers on Logistics in EU Countries., Nase More 65(4), 259-265,

doi:10.17818/NM/2018/4SI.18>

Nariadenie Európskeho parlamentu a Rady č. 1071/2009, ktorým sa ustanovujú spoločné pravidlá týkajúce sa podmienok, ktoré je potrebné dodržiavat' pri výkone povolania prevádzkovatel'a cestnej dopravy, 2009.

Nariadenie Európskeho parlamentu a Rady č. 1072/2009 o spoločných pravidlách prístupu nákladnej cestnej dopravy na medzinárodný trh, 2009.

Nariadenie Európskeho parlamentu a Rady č. 1073/2009 o pravidlách prístupu na medzinárodný trh autokarovej a autobusovej dopravy, 2009.

Nariadenie Európskeho parlamentu a Rady (EÚ) 2020/1054, ktorým sa mení nariadenie (ES) č. 561/2006, pokial' ide o minimálne požiadavky na maximálne denné a týždenné časy jazdy, minimálne prestávky a doby denného a týždenného odpočinku, a nariadenie (EÚ) č. 165/2014, pokial' ide o určovanie polohy prostredníctvom tachografov, $\mathbf{2 0 2 0 .}$

Nariadenie Európskeho parlamentu a Rady (EÚ) 2020/1055, ktorým sa menia nariadenia (ES) č. 1071/2009, (ES) č. 1072/2009 a (EÚ) č. 1024/2012 s ciel'om prispôsobit' ich vývoju v odvetví cestnej dopravy, 2020.

Nariadenie Európskeho parlamentu a Rady (EÚ) 2020/1056 o elektronických údajoch o nákladnej doprave, 2020.

Nariadenie Komisie (EÚ) 2016/403 z 18. 03. 2016, ktorým sa dopĺn̆a nariadenie Európskeho parlamentu a Rady (ES) Ā. 1071/2009 v súvislosti s klasifikáciou závažných porušení predpisov Únie, ktoré môžu viest' k strate bezúhonnosti prevádzkovatel'a cestnej dopravy, a ktorým sa mení príloha III k smernici Európskeho parlamentu a Rady 2006/22/ES, 2016.

Poliak, M., Gnap, J., 2020. Práca vodičov nákladných automobilov a autobusov. EDIS - vydavatel'stvo ŽU, Žilina, ISBN 978-80-554-1715-8.

Poliak, M., Poliaková, A., Čulík, K., 2020. Impact of the Social Law on Truck Parking Sustainability in the EU. Sustainability 12, no.22:9430. https://doi.org/10.3390/su12229430

Ministerstvo vnútra SR, 2021, Štatistika počtu evidovaných vozidiel v SR, dostupné online: https://www.minv.sk/?celkovy-pocet-evidovanych-vozidiel-v-sr, [cit.: 2021, 03. 05.].

Moravčík, L'., 2020, Typové schval'ovanie autonómnych (samojazdiacich) vozidiel. Perner's Contacts 15. , no 2. https://doi.org/10.46585/pc.2020.2.1642

Rada Európskej únie zo dňa 07. 04. 2020, Balík opatrení v oblasti mobility: Rada prijala reformu týkajúcu sa vodičov nákladných vozidiel; dostupné online: https://www.consilium.europa.eu/sk/press/pressreleases/2020/04/07/mobility-package-council-adopts-truck-drivers-reform/, 2020.

Slovenská republika, 1991, Zákon č. 455/1991 Zb. o živnostenskom podnikaní, dostupné online: https://www.slov-lex.sk/pravne-predpisy/SK/ZZ/1991/455/20210219.html.

Slovenská republika, 2007, Zákona č. 462/2007 Z. z. o organizácii pracovného času v doprave a o zmene a doplnení zákona č. 125/2006 Z. z. o inšpekcii práce a o zmene a doplnení zákona č. 82/2005 Z. z. 
o nelegálnej práci a nelegálnom zamestnávaní a o zmene a doplnení niektorých zákonov v znení zákona č. 309/2007 Z. z., https://www.slov-lex.sk/pravne-predpisy/SK/ZZ/2007/462/20200101

Smernica Európskeho parlamentu a Rady (EÚ) 2020/1057, ktorou sa stanovujú špecifické pravidlá vo vzt'ahu k smernici 96/71/ES a smernici 2014/67/EÚ pre vysielanie vodičov v odvetví cestnej dopravy a ktorou sa mení smernica 2006/22/ES, pokial' ide o požiadavky týkajúce sa dodržiavania predpisov, a nariadenie (EÚ) č. 1024/2012, 2020.

Slovenská národná akreditačná služba, 2021, Zoznam autorizovaných a registrovaných dielní; https://ais.snas.sk/ais/\#!WebReports/1/list.accredited.subject.search.byfield/AccreditedSubjectsByFiel ds, [05. 05. 2021]. 